\title{
Information and communication technology adoption in the Italian road freight haulage industry
}

\begin{abstract}
Despite the importance of information and communication technology (ICT) in the management of transport and logistics systems, there is a shortage of studies in the road freight haulage sector. This paper is aimed at filling this void through an exploratory survey on ICT adoption and the influencing factors carried out in the Italian road transport market. The paper provides a review of the previous research on this topic that allows the identification of research gaps that have been addressed through a questionnaire survey. The findings provide evidence of a passive stance on ICT usage characterised by the adoption of isolated applications. The financial risk associated with technology investment and human resources are the main barriers to ICT adoption, while the improvement of service level and the reliability of transport operations emerge as stimulating factors. The results suggest that the potential benefits of technology have not been fully exploited and a risk-sensitive stance on ICT is evident preventing the full incorporation of ICT into business processes.
\end{abstract}

Keywords: Information and communication technology, Adoption, Influencing factors, Road freight haulage, Italy, Questionnaire survey

\section{Introduction}

The rapid development of information and communication technology (ICT) has resulted in reduced investment and operational costs (Esposito and Mastroianni, 2002) and ICT applications are viewed as a key tool to improve the efficiency and responsiveness of modern supply chain operations (Hazen and Byrd, 2012). In the field of freight transport and logistics, there has been a proliferation of systems and technical infrastructures supporting various 
business activities (Giannopoulos, 2004). In this context, ICT has the potential to reduce costs and improve customer service, thereby enhancing overall competitive advantage (Forslund, 2012).

The road transport sector is a good example of an industry characterised by extreme competitive pressures, with customers demanding higher service levels combined with lower prices. In such an environment, the competitiveness of road transport companies is increasingly dependant on their ability to embrace innovation (Wagner, 2008). One of key driver of innovation in the road freight haulage industry in ICT (McKinnon, 2009) and the main benefits associated with the adoption of ICT in road haulage include improved responsiveness to rapidly changing customer requirements and uncertainty (Normandeau et al., 2003; Schönberger and Kopfer, 2012), reduced costs through the optimisation of transport operations (Tjokroamidjojo et al., 2006) and enhanced safety (Siror, et al., 2011).

However, despite the potential benefits of ICT usage, a number of studies suggest that the level of ICT adoption in the road freight transport industry has not kept pace with the rapid technological advances and decreases in the cost of technology (e.g. Higginbottom, 2002; Golob and Regan, 2002; Stefansson and Woxenius, 2007; McKinnon, 2009). In addition, the unequal access to ICT usage and benefits between large and small companies has produced huge digital divide (Bruno et al., 2011) in the EU transport and logistics service industry as documented in a study of the European Commission (e-Business Watch, 2008). Large companies have derived substantial benefits from technology usage as they are able to adopt more sophisticated ICT systems and applications than their smaller counterparts. This is a particularly critical in those markets populated by a high proportion of small companies as is the case of the Italian freight transport and logistics service market (Evangelista and Morvillo, 2000). 
From the research point of view, there is a shortage of studies investigating the adoption of ICT applications in the road haulage sector. This study is aimed at filling this gap through an exploratory survey of a sample of road hauliers based in Italy. The paper summarises the results of the survey and provides insights into the current and future usage of ICT applications, as well as identifying the main factors influencing technology adoption.

Following this introduction, the paper discusses the role of ICT in road freight transport on the basis of previous research. This is followed by an overview of the key characteristics of the Italian road freight transport industry and the ICT diffusion on the basis of existing studies. The authors' survey methodology is then described and the main findings presented. The concluding section discusses the results, leading to the identification of implications and possible directions for further research.

\section{The role of ICT in road haulage}

As a result of supply chain globalisation, transport and logistics activities have become more complex and decision support tools are increasingly necessary to coordinate and manage transport and logistics operations (Manuj and Sahin, 2011).

The road haulage industry is characterised by a range of environmental and societal pressures, as well as ever-increasing customer demands for higher service levels at lower cost. In this scenario, road hauliers are required to offer new and innovative ways to improve the efficiency of transport operations in order to fulfil the demand to move freight on time and reliably, as well as with greater visibility and lower environmental impact (Thomson, 2010).

The higher level of uncertainty (in the form of delays, lack of coordination, delivery constraints and variable demand) characterising the competitive landscape in today's road haulage industry may also negatively impact on costs and customer service levels (SanchezRodrigues et al., 2010). Information usage and sharing has a key role in improving transport 
operations efficiency (Nagarajan et al., 2005). For example, trucks can be delayed by accidents, traffic congestion, adverse weather conditions and breakdowns. Many of these delays can be prevented by enhanced information availability with, for example, in-cab devices providing instant communication and information including traffic alerts that can be used to avoid potential problems. Moreover, such information can be used to re-route vehicles and to alert shippers and receivers of potential delays.

This example shows how ICT is driving road haulage companies towards more efficient and effective operations (Cetinceviz and Bayindir, 2012). There is a general consensus on the fact that ICT applications can enable the exchange and sharing of critical information, thus facilitating better decision-making and firm performance (Evangelista, et al., 2012). In particular, the main benefits associated with the use of ICT applications in road transport may be summarised as follows: 1) improved route planning and transport scheduling; 2) better tracking of vehicles and goods along the shipment process; 3) faster transport operations as a result of more efficient data gathering and analysis; 4) improved documentation of transactions; and, 5) higher levels of coordination and integration between different road hauliers and other supply chain participants.

Despite these potential benefits, investment levels in ICT have been relatively modest in the sector. Wagner (2008) documented how the German transport industry spends some $1.1 \%$ of its turnover on innovation and development, compared to other sectors with levels that range from $4.8 \%$ to $17.8 \%$. McKinnon (2009) demonstrated that the rate of diffusion of ICT tools (such as digital tachograph, vehicle tracking systems and fuels economy improvement technologies) in the road freight transport sector has been relatively slow. He also noted:

“...when new equipment and systems are acquired, hauliers often fail to exploit their full potential. The reluctance to innovate and the failure to maximise the benefits of 
innovation can be attributed to a range of factors, some internal to haulage businesses, others externally controlled" (McKinnon 2009, p. 2).

This situation is reflected in a number of academic papers that strongly emphasise the positive effects of ICT usage (Baumgartner et al., 2008; Stefansson and Lumsden, 2009). However, few empirical studies (particularly questionnaire surveys) have been conducted on ICT adoption in the road freight sector over the last decade. For example, Perego et al. (2011) note that, while a relatively large number of research papers on ICT for transportation and logistics have been published since 1994 (44 in total), very few of them are exclusively focused on the road freight transport industry. In some papers, ICT adoption in the road haulage is considered as one of the segments that comprises the wider logistics service sector. The findings of these studies are not necessarily, therefore, applicable to the road haulage sector given its many unique characteristics. An analysis of the previous research investigating ICT adoption in the specific context of the road haulage industry over the last ten years evidenced that only seven questionnaire surveys have been conducted (see table 1). Most of these surveys focussed on the types of ICT applications adopted and the related benefits, while motivators and barriers affecting ICT usage have not been specifically investigated.

\section{Insert table 1 here}

The survey carried out by CSST and Cranfield University (2002) highlighted the strategic importance of telematics and mobile communications for road haulage companies. Telematics can contribute to improve business performance through cost reduction, improvements in customer service levels, and delivery reliability and consistency. Analysis of specific applications highlights that road haulage companies are likely to move from pre-planned transportation operations towards more dynamic systems that can react effectively to realtime events. There were relatively high levels of track-and-trace functionality in the surveyed companies, together with driver hours monitoring systems as a result of increasing restrictions 
and responsibilities associated with the EU working time directive. The high level of investment and running costs were considered constraints to wider technology implementation.

The work of Golob and Regan (2002) surveyed 1,200 road haulage companies to explore perceptions concerning three different types of ICT applications: those potentially used by dispatchers; those used by drivers directly; and, advanced traveller information systems. The authors developed a model linking operational characteristics of the companies investigated with their opinions about the relative usefulness of various sources of traffic information. The results indicated that evaluations of the above applications are primarily related to the location of operations, the average length of the company's load moves, and the provision of intermodal services.

The second paper by Golob and Regan (2003) focussed on routing and scheduling software adoption using data concerning almost 700 road haulage companies operating in California. The authors tested the relationship between managers' perceptions of the impact of traffic congestion on their operations and the adoption of routing and scheduling software. Demand for this type of software was found to be influenced directly by the need to re-route drivers, and indirectly by the need to operate during congested periods as result of customer schedules.

The study of McClelland and McKinnon (2004) was aimed at assessing how vehicle telematic systems can be used as a source of key performance indicator (KPI) data for measuring road transport efficiency in the UK. The results of the survey indicated that the main type of applications on which road transport companies focused were those that facilitated cost reduction in areas such as fuel consumption and driver hours.

The study conducted by Freight Transport Association (2005) also analysed the use of telematics in the UK road haulage sector. This study provides insights into the general 
benefits of telematics, methods of contacting drivers, the use of vehicle tracking systems and some of the reasons for not investing in this technology.

The survey developed by Davies et al. (2007) investigated the extent to which ICT was used by 46 general haulage companies in the UK market, with particular reference to Internet freight exchanges. The paper specifically explored ICT usage by UK general haulage operators, the efficiency of the general haulage fleet in terms of empty running, the sources and methods used to find backloads and the benefits of - and barriers to - the use of freight exchanges from hauliers' perspectives.

Finally, the paper of Sternberg et al. (2011) discussed the reduction of inefficiencies as result of the adoption of ICT through a survey of 20 less-than-truckload (LTL) companies in Germany, Sweden and Switzerland. These companies are involved specifically in the transportation of relatively small freight. The results indicate that the benefits of ICT usage are primarily in terms of reduced working hours, more efficient administration and reduced waiting times. Further benefits that could be achieved were regarded as being dependent upon wider adoption of ICT by other supply chain actors.

There is little doubt that the effective use of ICT has the potential to optimise road transport operations and significantly improve their efficiency and effectiveness. The surveys reported above provide some limited insights into the ICT applications adopted and their benefits. The motivators and barriers affecting ICT usage have been largely ignored. The research described in this paper aims to fill this gap in the specific context of the Campania region of southern Italy. The next section provides a brief analysis of the Italian road haulage market and summary analysis of the available studies conducted on ICT usage in the sector. 


\section{An overview of the Italian road freight transport industry}

This section describes the research context of this paper. It provides an overview of the Italian road haulage sector in the context of the wider contract transport and logistics service market. The Italian transport and logistics service industry is estimated to be the fifth largest European market after Germany, the UK, France and Benelux (Confetra and A.T.Kearney, 2010) and its value was estimated at around $€ 40$ billion in 2010 with an annual growth rate of $3.3 \%$ (Politecnico di Milano, 2012). The road haulage segment represents the most important contribution (36\%) to the value of the sector followed by freight forwarders (26\%), third party logistics providers (19\%), express couriers (11\%) and other provider types such as intermodal terminal operators, warehouse service providers and rail and combined transport companies $(8 \%)$.

As in the rest of the European Union, most goods are transported by road in Italy (European Commission, 2011). Italian Ministry of Infrastructure and Transport data show that road transport accounted for almost $60 \%$ of total tonne-kilometres $(\mathrm{tkm})$ moved domestically in 2011 (Ministero delle Infrastrutture e dei Trasporti, 2012) as shown in table 2.

\section{Insert table 2 here}

According to Eurostat data, total employment in the Italian road freight industry was 349,000 people in 2008 (European Commission, 2011).

Road transport is the backbone of the Italian freight transport and logistics industry but its structure is highly fragmented. Data of the Italian Register for Road Hauliers provides evidence of this high level of fragmentation in the sector (Albo Nazionale Autotrasportatori Italiani, 2011). It reports that the total number of road freight companies operating in the Italian market was 167,674 in 2010 . As shown in table 3 , the vast majority of these firms $(81.7 \%)$ own less than three vehicles, with only $6 \%$ of companies owning more than ten vehicles. The small size of most Italian road haulage firms has resulted in them operating as 
local or regional subcontractors for larger domestic or foreign hauliers and logistics providers. Consequently, these companies face fierce price competition leading to downward pressure on profit margins.

\section{Insert table 3 here}

The fragmentation of the industry, together with the opening of the market due to EU directives, has fuelled a growing interest in the Italian market by large multinational competitors in recent years. In addition, road transport companies from Central and Eastern European countries with lower wages and, therefore, more competitive operating costs, have also entered the Italian market. The number of foreign companies operating in the Italian road haulage market increased from 1\% in 2004 to 7\% in 2011 (Ministero delle Infrastrutture e dei Trasporti, 2012).

This competitive scenario presents Italian road hauliers two broad strategic options: (i) survive in the low-cost world of transportation carriers providing full haulage services and use price as the main competitive leverage; or, (ii) differentiate the product offering through ICT and other forms of innovation.

Despite the potential of ICT in this sector, there have been few investigations into this issue in the Italian road transport industry (see table 4).

\section{Insert table 4 here}

The study of CSST and Cranfield University (2002) indicated low penetration of telematics in the road transport sector mainly due to high implementation and running costs, and associated long investment payback periods. Another survey conducted by the Italian Freight Leaders Council (2003) showed that the telephone was the most widely used communication tool in road haulage firms, while the use of web-based technologies was still limited. A survey conducted by the Italian Ministry of Infrastructure and Transport (2004) documented how 
information technology was predominantly used for administration and accountancy purposes. E-mail services were used by $60 \%$ of the surveyed companies, while only $33 \%$ of companies adopted software to support transport operations. The survey also indicated that technology is much more widely used by larger hauliers than their smaller counterparts. Finally, a survey conducted by the Italian Register for Road Haulage (Albo Nazionale Autotrasportatori Italiani, 2008) on a sample of 1,000 road transport companies in 2008 indicated that about $70 \%$ of surveyed companies had not invested in ICT applications that support transport and warehousing operations and that no investments were planned for the following three years. Only $15 \%$ of surveyed firms planned any investment in ICT over the following three years.

The overall picture emerging from the above studies is fragmented in terms of the level and nature of ICT adoption in the sector. Moreover, excluding the CSST and Cranfield University study (2002) of more than a decade ago, none of the above surveys investigated the drivers of, and barriers to, ICT adoption. This strongly points to the need for an in-depth understanding of the existing level of technology capability, the applications currently used, areas of future investment and the main drivers and enablers of ICT adoption in Italian road haulage companies. The next section describes the methodology employed by the authors aimed at developing such an understanding through the use of a survey of ICT adoption in a sample of Italian road haulage companies.

\section{Survey methodology}

The exploratory study described in this paper is aimed at providing insights into the current and future state of ICT practices in the Italian road haulage industry, as well as into the factors affecting technology usage. To this end, a questionnaire survey has been carried out in a sample of companies operating in the Campania region of southern Italy. 
This area has been chosen for two main reasons. Firstly, due to its geographical position Campania region has the potential to play a significant role in the evolving Mediterranean logistics landscape by facilitating interconnections between European industrial and consumer areas and Northern Africa and the Middle East. In this context, the importance of road transport in the Campania region is expected to increase to support the outflow of goods from its main maritime ports (Naples and Salerno) to inland locations. Secondly, the structure of the road transport industry in the Campania region reflects the national industry situation reasonably well. For example, the road haulage company distribution by fleet size in the Campania region (see table 5) is quite similar to firm size distribution at national level shown in table 4 above.

\section{Insert table 5 here}

The specific objectives of the empirical investigation are as follows:

1) to investigate current and future ICT practices for supporting company operations; and,

2) to identify the main factors affecting ICT adoption.

The survey methodology has been organised into five main phases, as summarised in figure 1 . After preparation of a draft questionnaire, interviews with key actors in the sector (such as managers of road haulage companies, ICT consultants, representatives of Italian transport and logistics associations, consultants, researchers and academics working in the field) were carried out in order to test the basic research objectives and the suitability of the questionnaire.

\section{Insert figure 1 here}

Based on the feedback provided by these informants, the draft questionnaire was reviewed and finalised. The final questionnaire has been structured into three main sections. The first section gathers information about operating characteristics of companies (structure, turnover, fleet size, number of employees, type of transport services provided, geographic scope, 
typologies of customers, services supplied beyond pure haulage). In line with objective 1 (above), the second section is aimed at investigating the current and future usage of ICT. In line with objective 2 (above), the third part is aimed at identifying the main factors influencing ICT adoption.

In a subsequent phase, the sampling frame was defined using a database provided by the Italian Federation of Road Hauliers (FAI), one of the largest Italian road haulage associations. The database comprises information concerning 1,133 companies (accounting for $9.3 \%$ of the total population of road haulage companies operating in the Campania region). Table 6 reports the distribution of companies in the sampling frame by employee and fleet size.

\section{Insert table 6 here}

For the purposes of this study, very small companies (the so called 'padroncini') have not been considered based on the assumption that the potential of ICT for these firms is likely to be marginal. Accordingly, companies owning a fleet size of five vehicles or less have been excluded from the survey. This is in line with an UK study conducted by McClelland and McKinnon (2004) that demonstrated how the use of ICT and telematics in road hauliers is not profitable for companies of this size. This point was reinforced during the interviews conducted by the authors to test the questionnaire. Interviewees indicated that investment in ICT is not a priority for such companies as the small number of trucks they own may be effectively managed through cheaper and more accessible technologies such as mobile phones. Thus, the sampling frame for the survey has been reduced from 1,133 to 688. The questionnaire was sent to all 688 of these companies. The total number of valid questionnaire received was 39 (i.e. a response rate 5.7\%). To detect any possible non-response bias, a twostep analysis was carried out. Firstly, a sub-sample of non-respondents was contacted for information about some key demographic characteristics (such as company age, company size and type of activity) to be compared with respondents. This step did not indicate any 
significant bias. In a subsequent step, the method adopted by Goode and Stevens (2000) was used. Accordingly, the usable responses were split into two sets, respectively of 19 and 20 responses based on the dates on which they were received. A Mann-Whitney and chi-squared analysis of three key demographic variables revealed insignificant differences between the two groups of companies.

To ensure data reliability and completeness, respondents were subsequently contacted by telephone in order to clarify unclear responses and/or to provide any missing data.

\section{Main findings}

In this section the results of the empirical investigation are presented, providing an overview of the relevant characteristics of the respondent companies, including their distribution by number of employees, fleet size, type of transport services provided, geographical scope and breadth of services provided beyond pure haulage. Data concerning the current and future usage of ICT and the factors affecting ICT adoption are then documented and discussed.

\subsection{Sample characteristics}

Table 7 shows the distribution of sample firms by number of employees and fleet size. As far as the first characteristic is concerned, only $7.7 \%$ of firms have less than 10 employees, while the majority (82\%) has between 10 and 50 . When considering fleet size, about $85 \%$ of respondents operate between 6 and 15 vehicles, while $15.4 \%$ operate more than 50 vehicles.

\section{Insert table 7 here}

Table 8 describes the types of transport services provided by the sample firms. Survey responses suggest that general truckload is predominant over specialised transportation such as liquid bulk, refrigerated or hazardous. It is interesting to note that the surveyed firms tend to either operate as general truckload carriers or to focus on one or two specialised types of 
transport; few firms span many different types of transport. This is not surprising considering the additional equipment usually required to perform many specialised types of transport. As far as their geographical scope is concerned, only a small percentage $(2.6 \%)$ of the surveyed firms operate exclusively at a regional level, while about $36 \%$ serve the wider European market.

\section{Insert table 8 here}

Finally, results concerning services provided in addition to pure haulage (see table 9) indicate that about $44 \%$ of companies do not supply any type of complementary or value-added service. Nevertheless, some firms show an interesting trend towards diversification of their service offerings, including warehousing $(15.4 \%)$, distribution $(7.7 \%)$ or both services in combination $(30.7 \%)$.

\section{Insert table 9 here}

\subsection{Current and future use of ICT applications}

The importance attached to ICT by the surveyed firms can be assessed by examining ICT costs as a percentage of total company costs. As shown in table 10, 25 out of the 39 surveyed companies spent less than $1 \%$ of their total costs on ICT. Just three companies spent more than $10 \%$, while 11 spent between $3 \%$ and $10 \%$. This suggests that, in term of financial resources, the role attributed to ICT remains relatively low in the sample firms.

\section{Insert table 10 here}

An interesting area of ICT application investigated concerns the provision of track-and trace (T\&T) capabilities by the surveyed companies. As shown in the figure 2 above, responses indicate that tracking and tracing is mainly operated by means of traditional paper-based methods (61.5\% of companies), while the use of electronic devices is very low. In this respect, it should also be noted that about $11 \%$ of respondents do not provide any $\mathrm{T} \& \mathrm{~T}$ 
service. Nevertheless, the results show an increasing sophistication in the planned future usage (defined as within the next 3 years) of such systems among surveyed firms in that traditional methods of information dissemination - paper-based and call centres - are expected to be substituted by web-based interfaces ( $43.6 \%$ of firms).

\section{Insert figure 2 here}

The survey asked companies to indicate the systems used for communication with drivers. As figure 3 indicates, communication by voice through mobile phone is the most widely used system (89.7\% of respondents).

\section{Insert figure 3 here}

Indeed, mobile phones have achieved a high penetration as a communication mechanism to drivers with nearly $90 \%$ of the respondents indicating that they have fitted mobile phones to their entire fleet. Survey results show a decrease for the next three years in traditional communication by voice through mobile phone, which will be gradually substituted by satellite-based and other systems. With regard to proof of delivery (POD) systems (figure 4), the results show that for the total sample POD is currently captured through paper-based signatures. However this is set to change with a high interest shown by respondents in realtime electronic signatures captured through some form of portable computing (as already used by most express couriers).

\section{Insert figure 4 here}

A similar picture emerges when looking at the current and future usage of systems for recording and managing delivery errors (damage, incorrect goods, wrong delivery addresses, etc.), as shown in figure 5. Indeed, the survey reveals clear evidence of a widespread usage of paper-based systems. Other systems currently used are driver debriefing at depots and telephone calls to depots. It is noteworthy that in this case the use of paper-based methods is 
also expected to significantly decrease in the future in favour of electronic systems, which allow less time to be spent on driver debriefing and re-keying from paper documents.

\section{Insert figure 5 here}

Another operational area of ICT application that was explored by the survey concerns routing and scheduling. This is an important area for the introduction of telematic applications since problems related to traffic congestion are leading to an increased demand for routing and scheduling software as shown by some earlier studies (Freight Leaders Council, 2003; Ministero delle Infrastrutture e dei Trasporti, 2004).

For the surveyed companies routing still relies largely on manual planning or is carried out by voice through mobile phone, but for the coming years the results suggest an increased level of adoption of dynamic routing and scheduling systems, which allow real time information to be managed by in-cab computers (figure 6).

\section{Insert figure 6 here}

As to the related but broader issue of Internet utilisation, a set of questions was included in the questionnaire to investigate the usage of corporate websites. This was deemed to be of importance given the potential offered by the Internet to enhance operational efficiency as well as customer service in the road haulage industry (Ellinger et al., 2003a). Of the 39 respondents, the majority (61.5\%) are operating a website. It is surprising that a large proportion of respondents (38.5\%) still have no web presence at all, especially considering the minimal operational costs usually required to implement a basic site with static pages. Not unexpectedly, most non-adopters are small companies with an average fleet size of 13 vehicles. This evidence is consistent with the findings of an earlier study conducted by Ellinger et al. (2003b), which revealed that logistics service providers without corporate websites tended to be smaller than those operating a corporate website. Using a list compiled from literature sources, as well as from the authors' interviews with logistics practitioners, the 
15 non-adopters were asked to indicate the main reasons why they have not implemented a corporate website. 'Our customers do not demand web-based services', 'we do not consider the website a necessary tool for our business' and 'our primary competitors do not use webbased applications' emerged as the most common reasons for non-adoption, followed by the cost of website implementation, and the cost and time for employee training (figure 7).

\section{Insert figure 7 here}

The survey asked companies to rate the importance of website functions on a 0 to 3 scale (with 3 indicating the highest importance). As figure 8 shows, the most important function of the websites in sample firms is the provision of company information/advertising, followed by improving relations with customers.

\section{Insert figure 8 here}

Beyond the use of websites, another issue relates to the use of freight exchanges. Such internet portals offer road transport companies the opportunity to load vehicles more often and to improve the rate of backloads with significant enhancement in their overall efficiency levels. The survey data did not reveal any usage of freight exchanges for addressing the empty running issue. Respondents do not consider that portals are reliable in terms of customer service and many see the need to retain the full control over shipments (particularly in the case of hazardous goods). In addition, the business model of these portals is predominantly based on linking supply and demand of transport services with little support beyond this basic functionality. The lower Internet penetration in Italy in comparison with other industrialized EU countries is an important factor that also negatively affects the use of freight exchanges by road transport companies. Another influencing factor is the small load capacities of Italian road haulage companies as a result of their small size - this limits the opportunity to use freight exchanges in a profitable way. 
The above findings reveal that the majority of firms are not using the Internet to its full potential as a tool for performing business transactions more efficiently and are consistent with the contention of the earlier study by Ellinger et al. (2003b), which indicated that road hauliers are not sufficiently leveraging web-based opportunities to improve their business processes.

\subsection{Factors influencing ICT adoption}

In this section an overview of the factors influencing the adoption of ICT in the sample firms is provided. The survey explored the factors stimulating current and planned future ICT adoption in the sample companies (figure 9). Unexpectedly, reduction of transport costs has been accorded relatively low importance while greater significance was attributed to servicerelated factors, with improved service levels cited as the most significant factor stimulating the current level of ICT adoption. This could be explained by the very high customer expectations perceived by respondents.

\section{Insert figure 9 here}

In comparison to the factors that have stimulated the current levels of ICT adoption, improvement of service levels and reliability are still the highest rated stimuli for planned future ICT adoption. However, there is a considerable increase in the average rating of transport cost reduction.

With regard to the factors inhibiting a wider adoption of ICT applications among companies, the survey provides some interesting results (see figure 10). The size of investment and implementation costs has been cited as the most influential factor inhibiting ICT adoption. This suggests a high level of financial risk aversion in the surveyed companies. A further class of factors with a strong impact on investment decision-making relates to organizational issues (e.g. the need to upgrade personnel skills and the resistance to organisational change). 
Less significance has been attached to the difficulties of integrating with customers' IT systems. Industry and standards-related factors (e.g. difficulties in the selection of ICT providers and lack of trust and confidentiality in technological standards) are not considered significant impediments to ICT investment.

\section{Insert figure 10 here}

\section{Discussion and conclusions}

The critical role played by road transport in the context of modern economies is undeniable. In order to increase the efficiency and reliability of transport operations and to remain competitive in the marketplace, road haulage companies are required to continuously innovate. ICT is likely to remain one of the most important areas of innovation for the foreseeable future. In addition, the current economic volatility has forced road transport companies to optimise costs and simultaneously improve service levels. ICT applications offer the potential to develop appropriate levels of customer service with a positive impact on the overall competitive position of road hauliers. This is particularly the case for smaller companies.

This study explored ICT adoption in a sample of Italian road haulage companies. The results indicate that the current penetration of ICT-based applications is generally low. This suggests that the potential benefits of technology have not been fully exploited and this is particularly true for web-based applications such as tracking and tracing, as well as the use of company websites and transportation web portals. Most of the operational activities considered in the survey are predominantly carried out using paper-based approaches or through mobile phone. The level of usage of more advanced applications providing real-time information about, for example, proof of delivery or routing and scheduling is relatively low but is expected to grow in the coming years. The lack of these applications also inhibits real-time monitoring of 
critical parameters for internal and external purposes. This evidence suggests that a lack of clarity in the management of customer relationships exists. The use of websites provides further support for this contention as most of the surveyed companies have justified their limited use on the grounds that customers do not currently require web-based services. In any case, where websites have been implemented, their usage is mainly aimed at providing company information. Finally, there also appears to be a lack of integration in the use of various ICT tools; this prevents firms from fully exploiting the potential of using different applications simultaneously. This suggests a risk-sensitive stance on ICT by the surveyed companies, resulting in the adoption of isolated applications that address different operational needs but without a company-wide integrated strategy and adequate planning to fully incorporate ICT into business processes.

There are two main underlying reasons for scenario depicted by the survey findings. The first relates to the financial and cost issues that have been identified as the most important factor inhibiting the use of technology. ICT applications are still seen as expensive especially by small road hauliers. For these companies there are difficulties in objectively evaluating the impact of ICT on cost and productivity, as well as on service levels and the concomitant opportunities to grow revenue through customer retention and the attraction of new customers. The second factor relates to the organisational dimension and it specifically concerns the updating of workforce skills and the organisational changes associated with ICT implementation. They are seen as major constraints on ICT adoption and, therefore, the exploitation of ICT potential.

This scenario suggests that ICT vendors may have an important role to play. These companies can stimulate the use of cooperative ICT platforms through which they may design solutions more closely aligned with the needs of road haulage companies, as well as facilitating a better appreciation of the benefits associated with the use of more innovative applications. 
Considering the proliferation of logistics-related ICT tools and applications in recent years, such initiatives could address some of the difficulties faced by road transport companies in the selection of appropriate tools for their businesses at a reasonable cost. In addition, this kind of initiatives has the potential to overcome some of the problems connected with the skills needs of road haulage companies.

In light of this situation, there appears to be a need to raise the level of awareness of ICT potential benefits in the road haulage sector. This has implications for future research in this area, which should provide further confirmation and quantification of the benefits of investing in these technologies. Deeper knowledge of the benefits of ICT usage may encourage these firms - in particular smaller companies - to change their approaches and to commit more resources to fully integrating ICT into their competitive strategies.

Notwithstanding its exploratory nature, the authors acknowledge that there are some limitations in the current research. These limitations provide further fruitful avenues for future research. The findings provide a snapshot in relation to ICT adoption at a specific point in time and in a particular region. Replication of the study in a longitudinal manner would enable a picture of the situation as it emerges over time to be developed. This would be particularly useful given the continuing rapid rate of technological development. Furthermore, administering the survey to a larger sample and beyond the Campania region would enhance the reliability of the data and facilitate generalisability. It would also allow comparisons to be made in terms of ICT adoption patterns in different regions and countries. Finally, given the largely exploratory nature of the issues under investigation, the execution of case studies and/or action research would allow deeper and richer insights into the observed phenomena to be generated. Interviews and focus groups involving key informants have potential as data collection techniques in the context of the execution of such methodologies. 


\section{References}

Albo Nazionale Autotrasportatori Italiani, 2011. Indagine relativa al monitoraggio del posizionamento delle aziende di autotrasporto. Ministero delle infrastrutture e dei trasporti e Comitato Centrale per l'Albo Nazionale Autotrasportatori Italiani, Servizio di monitoraggio sulle Attivita' delle Aziende di autotrasporto, Survey Report, Rome, Italy (in Italian).

Albo Nazionale Autotrasportatori Italiani, 2008. L'autotrasporto: una radiografia del settore dopo la 32/2005. Research Report, Rome, Italy (in Italian).

Baumgartner, M., Leonardi, J., Krusch, O., 2008. Improving computerized routing and scheduling and vehicle telematics: a qualitative survey. Transportation Research Part D: Transport and Environment. 13(6), 377-382.

Bruno, G., Esposito, E., Genovese, A., Gwebu, K.L., 2011. A critical analysis of current indexes for digital divide measurement. The Information Society: an International Journal. 27(1), pp. 16-28.

Centro Studi sui Sistemi di Trasporto (CSST), Cranfield University, 2002. Transport and Logistics in the digital era: A survey of telematic use by European Road Freight Operators. Survey Report, Fiera di Genova, October 28-29, Genoa, Italy.

Cetinceviz, Y., Bayindir, R., 2012. Design and implementation of an internet based effective controlling and monitoring system with wireless fieldbus communications technologies for process automation - an experimental study", ISA Transactions. 51, 461-70.

Confetra, A.T.Kearney, 2010. Scenario della logistica in Italia. Sintesi delle evidenze. December, Milan, Italy (in Italian).

Davies I., Mason R., Lalwani C., 2007. Assessing the impact of ICT on UK general haulage companies. International Journal of Production Economics. 106, 12-27.

e-Business Watch, 2008. The European e-Business Report - The Impact of ICT and eBusiness on Firms, Sectors and the Economy, $6^{\text {th }}$ Synthesis Report of the Sectoral eBusiness Watch, DG Enterprise \& Industry, European Commission.

Ellinger, A. E., Lynch, D. F., Andzulis, J. K., Smith, R. J., 2003a. B-to-B E-commerce: a content analytical assessment of motor carrier websites. Journal of Business Logistics. 24 (1), 199-220.

Ellinger, A. E., Lynch, D. F., Hansen, J. D., 2003b. Firm size, web site content, and financial performance in the transportation industry. Industrial Marketing Management. 32(3), 177185.

Esposito, E., Mastroianni, M., 2002. Information technology and personal computers: the relational life cycle, Technovation. 22(1), 41-50.

European Commission, 2011, EU Transport in Figures. Statistical Pocketbook 2011, Luxembourg, Office for Official Publications of the European Communities.

Evangelista, P., Mogre, M., Perego, A., Raspagliesi, A., Sweeney, E., 2012. A survey based analysis of IT adoption and 3PLs' performance. Supply Chain Management: An International Journal. 17(2), 172-186

Evangelista, P., Morvillo, A., 2000. Maritime transport in the Italian logistics market. Maritime Policy \& Management. 27(4), 335-352.

Forslund, H., 2012. Performance management in supply chains: logistics service providers' perspective. International Journal of Physical Distribution \& Logistics Management. 42(3), 296- 311.

Freight Leaders Council, 2003. Flussi informativi nel trasporto merci e nella logistica. Criticità, stato dell' arte e proposte. Quaderno n. 14, Milan, Italy (in Italian).

Freight Transport Association, 2005. Telematics Guide. FTA, Tunbridge Wells, UK.

Giannopoulos, G.A., 2004. The application of information and communication technologies in transport. European Journal of Operational Research. 152(2), 302-320. 
Golob, T. F., Regan, A. C., 2003. Traffic congestion and trucking managers' use of automated routing and scheduling. Transportation Research Part E, 39 (1). 61-78.

Golob, T.F., Regan, A.C., 2002. The perceived usefulness of different sources of traffic information to trucking operations. Transportation Research Part E. 38(2), 97-116.

Goode, S., Stevens, K., 2000. An analysis of the business characteristics of adopters and nonadopters of WWW. Technology Information and Management. 1(1), 129-154.

Hazen, B.T., Byrd, T.A., 2012. Toward creating competitive advantage with logistics information technology, International Journal of Physical Distribution \& Logistics Management. 42(1), 8-35.

Higginbottom, D., 2002. Digital tachographs a challenging change, Logistics and Transport Focus. December, 39-41.

Manuj, I., Sahin, F., 2011. A model of supply chain and supply chain decision-making complexity. International Journal of Physical Distribution \& Logistics Management, 41(5), 511-549.

McClelland, D., McKinnon, A., 2004, Use of vehicle telematics systems for the collection of key performance indicator data in road freight transport. Heriot Watt University, UK,

McKinnon, A., 2009. Innovation in road freight transport: achievements and challenges. Paper prepared for the International Transport Forum/IMTT Seminar on Innovation in Road Transport: Opportunities for Improving Efficiency. $2^{\text {nd }}$ October 2009, Lisbon, Portugal.

Ministero Infrastrutture e Trasporti, 2012, Conto Nazionale delle Infrastrutture e dei Trasporti - Anni 2010-2011, Dipartimento per i Trasporti, la Navigazione ed i Sistemi Informativi e Statistici, Direzione Generale per i Sistemi Informativi, Statistici e la Comunicazione, Ufficio di Statistica, Rome, Italy (in Italian).

Ministero delle Infrastrutture e dei Trasporti, 2004, "Indagine conoscitiva su 2.000 imprese che esercitano l'autotrasporto di cose per conto di terzi", Comitato Centrale per l'Albo nazionale delle persone fisiche e giuridiche che esercitano l'autotrasporto di cose per conto terzi, Vol. 2, July, Roma, Italy (in Italian).

Nagarajan, A., Canessa, E., Maciek, N., Will M., White III C.C., 2005. Technology in Trucking. Published in Belman, D., White III, C.C. (eds.). Trucking in the age of information. Ashgate Publishing Ltd. Burlington VT, 147-182.

Normandeau, G., Roy, J., Isaac, H., 2003. New technologies of information and communications and the consolidation of transport supply in the trucking industry. Proceedings of the CTRF Annual Conference, May 11-14, Ottawa, Canada.

Perego, A., Perotti, S., Mangiaracina, R., 2011. ICT for logistics and freight transportation: a literature review and research agenda. International Journal of Physical Distribution and Logistics Management. 41(5), 457-483.

Politecnico di Milano, 2012. Outsourcing della Logistica: le potenzialità di crescita e innovazione. Osservatorio Contract Logistics, November, Milan, Italy (in Italian).

Sanchez-Rodrigues, V., Potter, A., Naim, M., 2010. Evaluating the causes of uncertainty in logistics operations. The International Journal of Logistics Management. 21, 45-64.

Schönberger, J. Kopfer, H., 2012. Revenue management in road-based freight transportation: Impacts of uncertainty of capacity consumption. International Journal of Physical Distribution \& Logistics Management. 42(4), 388-403.

Siror, J.K., Huanye, S., Dong, W., 2011. RFID based model for an intelligent port. Computers in Industry. 62(8-9), 795-810.

Stefansson, G., Lumsden, K., 2009. Performance issues of smart transportation management systems. International Journal of Productivity and Performance Management. 58(1), 55-70.

Stefansson, G., Woxenius, J, 2007. The concept of smart freight transport systems - The road haulier's perspective. Proceedings of the $19^{\text {th }}$ Annual NOFOMA Conference, 7-8 June, Reykjavik, Iceland, 1007-1023. 
Sternberg, H., Prockl, G., Holmström, J., 2011. ICT in road transport operations analyzing potential effects on individual activity level, Proceedings of the $23^{\text {rd }}$ Annual NOFOMA Conference Logistics and Supply Chain Management in a High North perspective, 9-10 June 2011, Harstad, Norway, 1243-1258.

Thomson, F., 2010. Truck IT Report. A brief analysis of eyefortransport's recent survey 2010. Eye for Transport Research Series. Georgetown, UK, Eye for Transport.

Tjokroamidjojo, D., Kutanoglu, E. \& Taylor, D. 2006. Quantifying the value of advance load information in truckload trucking. Transportation Research: Part E. 42(4), 340-357.

Wagner, S.M., 2008. Innovation management in the German transportation industry. Journal of Business Logistics. 29(2), 215-231. 
Table 1. Summary of previous questionnaire surveys on ICT in the road freight transport industry

\begin{tabular}{|c|c|c|c|c|c|c|}
\hline Author (year) & $\begin{array}{l}\text { Country } \\
\text { involved in } \\
\text { the survey }\end{array}$ & $\begin{array}{l}\text { Sample } \\
\text { size }\end{array}$ & $\begin{array}{c}\text { ICT } \\
\text { application } \\
\text { s adopted }\end{array}$ & $\begin{array}{c}\text { Drivers } \\
\text { of ICT } \\
\text { adoption }\end{array}$ & $\begin{array}{l}\text { Barriers to } \\
\text { ICT } \\
\text { adoption }\end{array}$ & $\begin{array}{l}\text { Benefits } \\
\text { of ICT } \\
\text { adoption }\end{array}$ \\
\hline $\begin{array}{l}\text { CSST and } \\
\text { Cranfield } \\
\text { University, } 2002\end{array}$ & $\begin{array}{l}\text { Some EU } \\
\text { countries }\end{array}$ & 122 & YES & NO & YES & YES \\
\hline $\begin{array}{l}\text { Golob and Regan, } \\
2002\end{array}$ & USA & 1,200 & YES & NO & NO & NO \\
\hline $\begin{array}{l}\text { Golob and Regan, } \\
2003\end{array}$ & USA & 712 & YES & NO & NO & NO \\
\hline $\begin{array}{l}\text { McClelland and } \\
\text { McKinnon, } 2004\end{array}$ & UK & 32 & YES & NO & NO & NO \\
\hline $\begin{array}{l}\text { Freight Transport } \\
\text { Association, } 2005\end{array}$ & UK & $\mathrm{n} / \mathrm{a}$ & YES & NO & $\mathrm{NO}$ & YES \\
\hline Davies et al., 2007 & UK & 46 & NO & NO & NO & YES \\
\hline $\begin{array}{l}\text { Sternberg et al., } \\
2011\end{array}$ & $\begin{array}{l}\text { Germany, } \\
\text { Sweden and } \\
\text { Switzerland }\end{array}$ & 20 & YES & NO & NO & YES \\
\hline
\end{tabular}

Table 2. Modal split of the Italian domestic freight transport industry 1990-2011 (tkm millions)

\begin{tabular}{l|rr|rr|rr|rr}
\hline Transport mode & \multicolumn{2}{|c|}{$\mathbf{1 9 9 0}$} & \multicolumn{2}{|c|}{$\mathbf{2 0 0 0}$} & \multicolumn{2}{|c|}{$\mathbf{2 0 0 5}$} & \multicolumn{2}{|c|}{$\mathbf{2 0 1 1}$} \\
\hline Rail & 21,911 & $11.5 \%$ & 25,053 & $11.6 \%$ & 22,761 & $9,6 \%$ & 18,240 & $9.1 \%$ \\
Short sea shipping & 35,665 & $18.6 \%$ & 33445 & $15.5 \%$ & 46,839 & $19,7 \%$ & 53,034 & $26.5 \%$ \\
Inland navigation & 118 & $0.1 \%$ & 170 & $0.1 \%$ & 89 & $0,04 \%$ & 107 & $0.1 \%$ \\
Air & 612 & $0,3 \%$ & 846 & $0.4 \%$ & 982 & $0,4 \%$ & 1,037 & $0.5 \%$ \\
Road (> 50 Km) & 12,4209 & $64.9 \%$ & 146,640 & $67.9 \%$ & 155,872 & $65,6 \%$ & 118,565 & $59.2 \%$ \\
Pipelines (> 50 Km) & 8,776 & $4.6 \%$ & 9,721 & $4.5 \%$ & 10,907 & $4,6 \%$ & 9,192 & $4.6 \%$ \\
Total & $\mathbf{1 9 1 , 2 9 1}$ & $\mathbf{1 0 0 \%}$ & $\mathbf{2 1 5 , 8 7 5}$ & $\mathbf{1 0 0 \%}$ & $\mathbf{2 3 7 , 2 8 7}$ & $\mathbf{1 0 0 \%}$ & $\mathbf{2 0 0 , 1 7 5}$ & $\mathbf{1 0 0 \%}$ \\
\hline
\end{tabular}

Source: Ministero delle Infrastrutture e dei Trasporti, 2012

Table 3. Distribution of Italian road hauliers by fleet size 2010

\begin{tabular}{c|c|c}
\hline $\begin{array}{c}\text { Vehicles } \\
\text { bands }\end{array}$ & $\begin{array}{c}\text { Number of } \\
\text { road hauliers }\end{array}$ & \% \\
\hline$\leq 3$ & 137,075 & 81.7 \\
$4-10$ & 20,488 & 12.3 \\
$>10$ & 10,111 & 6.0 \\
Total & $\mathbf{1 6 7 . 6 7 4}$ & $\mathbf{1 0 0 . 0}$ \\
\hline
\end{tabular}

Source: Albo Nazionale Autotrasportatori Italiani, 2011 
Table 4. Summary of questionnaire surveys conducted in the Italian road freight transport industry

\begin{tabular}{l|c|c|c|c|c}
\hline \multicolumn{1}{c|}{ Author (year) } & $\begin{array}{c}\text { Sample } \\
\text { size }\end{array}$ & $\begin{array}{c}\text { ICT } \\
\text { applications } \\
\text { adopted }\end{array}$ & $\begin{array}{c}\text { Drivers of } \\
\text { ICT } \\
\text { adoption }\end{array}$ & $\begin{array}{c}\text { Barriers to } \\
\text { ICT } \\
\text { adoption }\end{array}$ & $\begin{array}{c}\text { Benefits of } \\
\text { ICT } \\
\text { adoption }\end{array}$ \\
\hline $\begin{array}{l}\text { CSST and Cranfield } \\
\text { University, 2002 }\end{array}$ & 24 & YES & NO & YES & YES \\
$\begin{array}{l}\text { Freight Leaders } \\
\begin{array}{l}\text { Council, 2003 } \\
\text { Italian Ministry of }\end{array}\end{array}$ & 31 & YES & NO & NO & NO \\
$\begin{array}{l}\text { Infrastructure and } \\
\begin{array}{l}\text { Transport, 2004 } \\
\text { Italian Register for } \\
\text { Road Haulage, 2008 }\end{array}\end{array}$ & 2,000 & YES & NO & NO & NO \\
\hline
\end{tabular}

Table 5. Distribution of road hauliers in Campania region by fleet size 2010

\begin{tabular}{ccc}
\hline $\begin{array}{c}\text { Vehicles } \\
\text { Bands }\end{array}$ & $\begin{array}{c}\text { Number of } \\
\text { road hauliers }\end{array}$ & $\boldsymbol{\%}$ \\
\hline$\leq 3$ & 8,631 & 70.2 \\
$4-10$ & 2,351 & 19.1 \\
$>10$ & 1,317 & 10.7 \\
Total & $\mathbf{1 2 , 2 2 9}$ & $\mathbf{1 0 0 . 0}$ \\
\hline
\end{tabular}

Source: Albo Nazionale Autotrasportatori Italiani, 2011

Table 6. Distribution of sample frame firms by fleet size 2010

\begin{tabular}{ccc}
\hline Vehicles bands & Number of firms & \% \\
\hline $1-5$ & 445 & 39.2 \\
$6-15$ & 499 & 44.0 \\
$16-50$ & 149 & 13.2 \\
$>$ 50 & 40 & 3.6 \\
Total & $\mathbf{1 , 1 3 3}$ & $\mathbf{1 0 0 . 0}$ \\
\hline
\end{tabular}

Table 7. Distribution of sample firms by number of employees and fleet size

\begin{tabular}{cccccc}
\hline Employees bands & $\mathrm{N}$ & $\%$ & Vehicles bands & $\mathrm{N}$ & $\%$ \\
\hline$<10$ & 3 & 7.7 & $1-5$ & 0 & 0 \\
$10-25$ & 19 & 48.7 & $6-15$ & 13 & 33.3 \\
$26-50$ & 13 & 33.3 & $16-50$ & 20 & 51.3 \\
$51-75$ & 1 & 2.6 & $>50$ & 6 & 15.4 \\
$76-100$ & 0 & 0.0 & Total & $\mathbf{3 9}$ & $\mathbf{1 0 0 . 0}$ \\
$>100$ & 3 & 7.7 & & & \\
Total & $\mathbf{3 9}$ & $\mathbf{1 0 0 . 0}$ & & & \\
\hline
\end{tabular}


Table 8. Type of transport performed by sample firms

\begin{tabular}{lcc}
\hline Type of service & Number of firms & \% of firms \\
\hline General truckload & 17 & 25.3 \\
General less-than-truckload & 13 & 19.5 \\
Hazardous & 10 & 14.9 \\
Pallets & 10 & 14.9 \\
Refrigerated & 6 & 8.9 \\
Container & 6 & 8.9 \\
Liquid bulk & 5 & 7.6 \\
Total & $\mathbf{6 7}$ & $\mathbf{1 0 0 . 0}$ \\
\hline
\end{tabular}

Note: the total is greater than the sample size as multiple responses were possible.

Table 9. Services provided beyond pure haulage

\begin{tabular}{lcc}
\hline \multicolumn{1}{c}{ Services } & Number of firms & \% of firms \\
\hline None & 17 & 43.6 \\
Warehousing only & 6 & 15.4 \\
Distribution only & 3 & 7.7 \\
Warehousing \& Distribution & 12 & 30.7 \\
Warehousing \& Distribution \& & 1 & 2.6 \\
Value-added services & $\mathbf{3 9}$ & $\mathbf{1 0 0 . 0}$ \\
Total & & \\
\hline
\end{tabular}

Table 10. ICT expenditure on total company costs

\begin{tabular}{lcc}
\hline $\begin{array}{c}\text { ICT costs (as a percentage of total } \\
\text { company costs) }\end{array}$ & $\begin{array}{c}\text { No. of } \\
\text { firms }\end{array}$ & $\%$ \\
\hline Less than $0.5 \%$ & 16 & 41.0 \\
From $0.5 \%$ to $1 \%$ & 9 & 23.0 \\
From $1.01 \%$ to $3 \%$ & 6 & 15.4 \\
From $3.01 \%$ to $10 \%$ & 5 & 12.8 \\
More than $10 \%$ & 3 & 07.8 \\
Total & $\mathbf{3 9}$ & $\mathbf{1 0 0}$ \\
\hline
\end{tabular}


Fig. 1. The survey methodology.

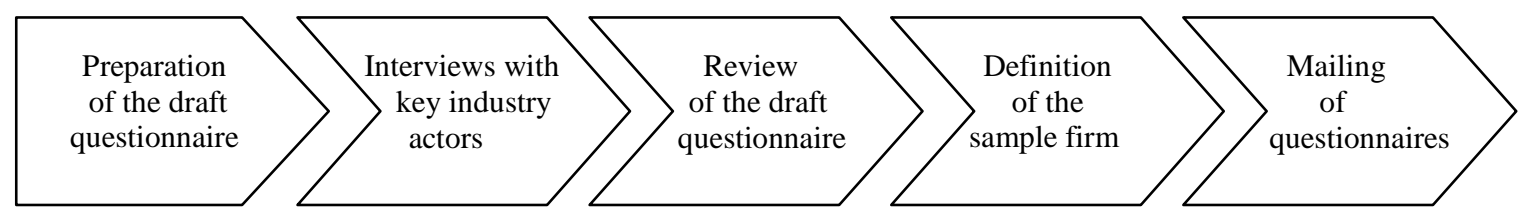

Fig. 2. Usage of track and trace systems.

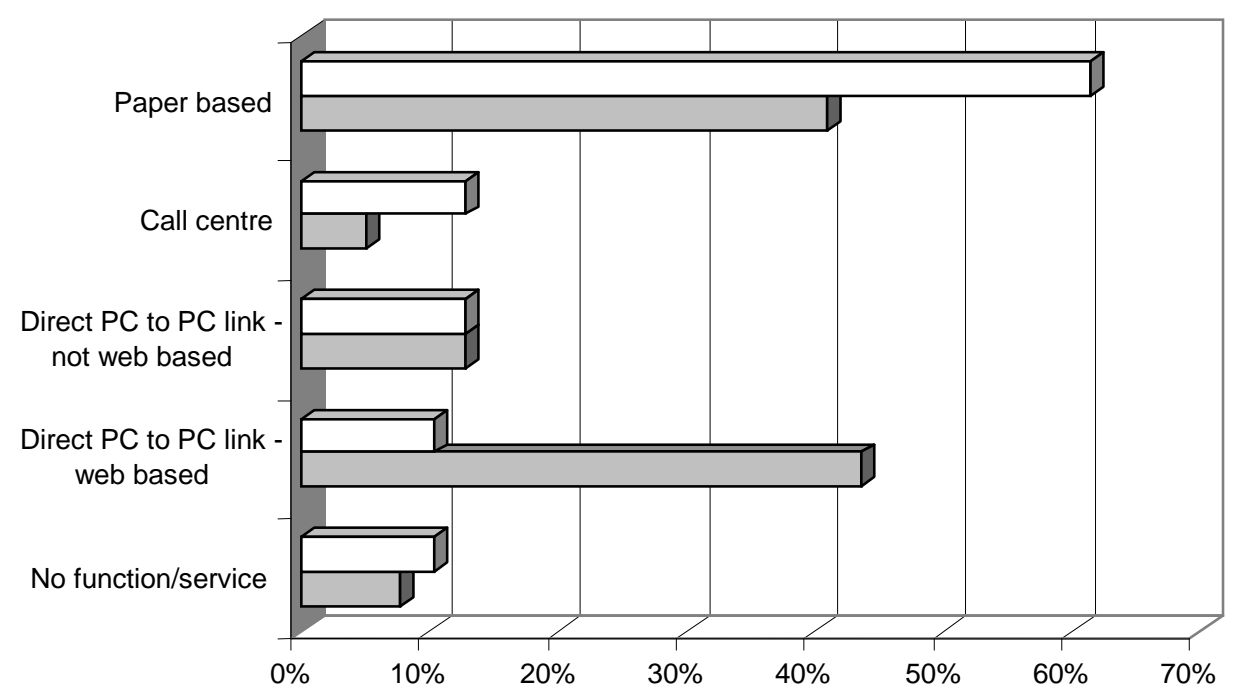

$\square$ Future $\square$ Current

Fig. 3. Usage of communication systems with vehicle/driver.

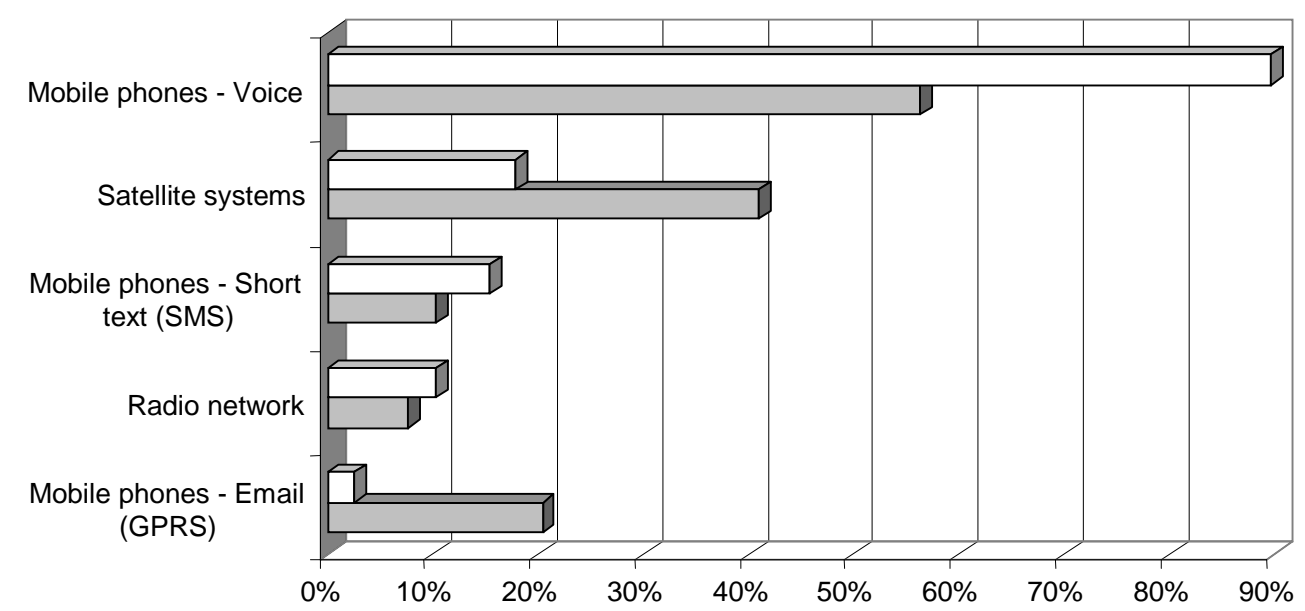

$\square$ Future $\square$ Current 
Fig. 4. Usage of proof of delivery (POD) systems.

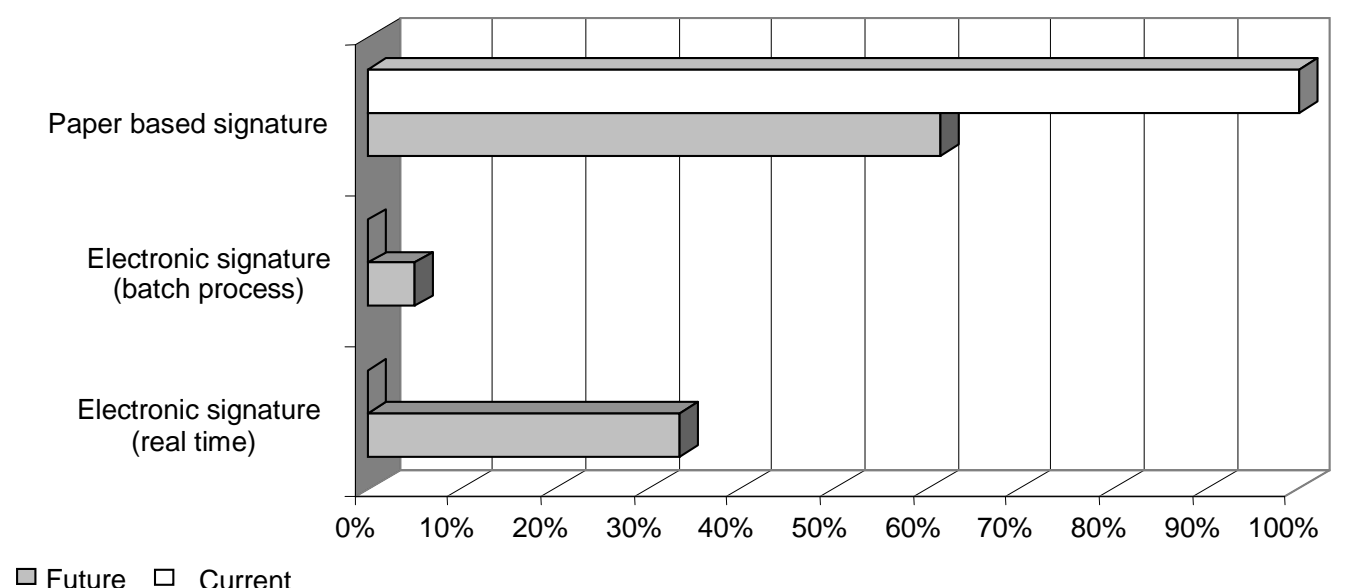

Fig. 5. Usage of systems for managing delivery errors.

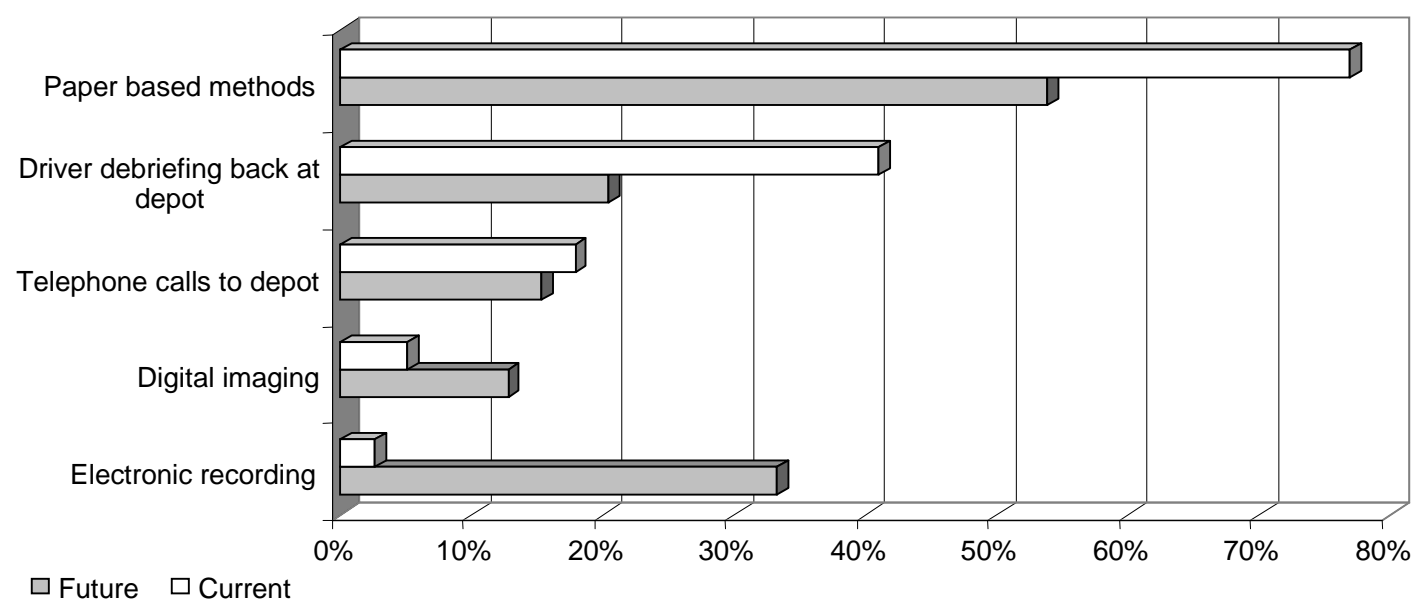

Fig. 6. Usage of routing and scheduling systems.

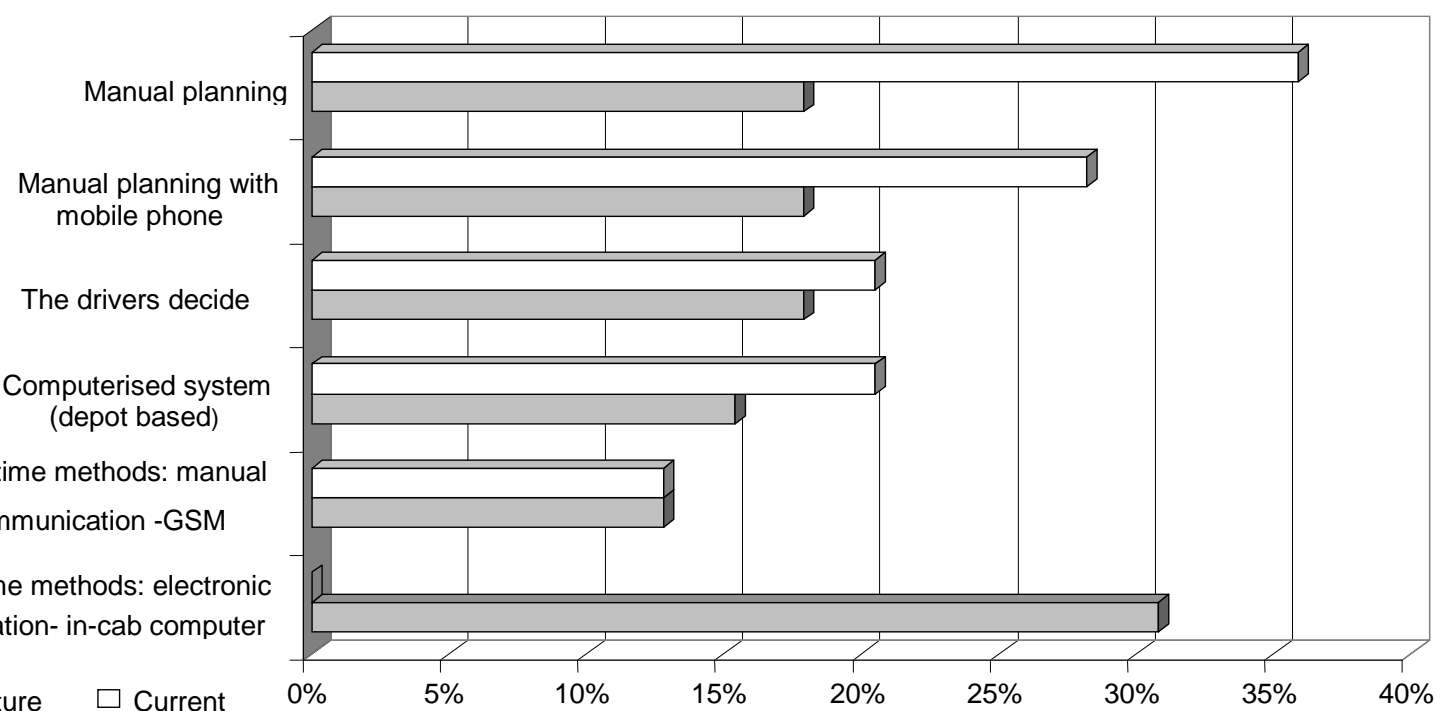


Fig. 7. Reasons for not implementing a website.

Customers do not require web-based services

Do not consider it a necessary tool for business

Competitors do not use web-based applications

Implementation costs

Costs and time for employees training

Data security concerns

Lack of experience in computer usage

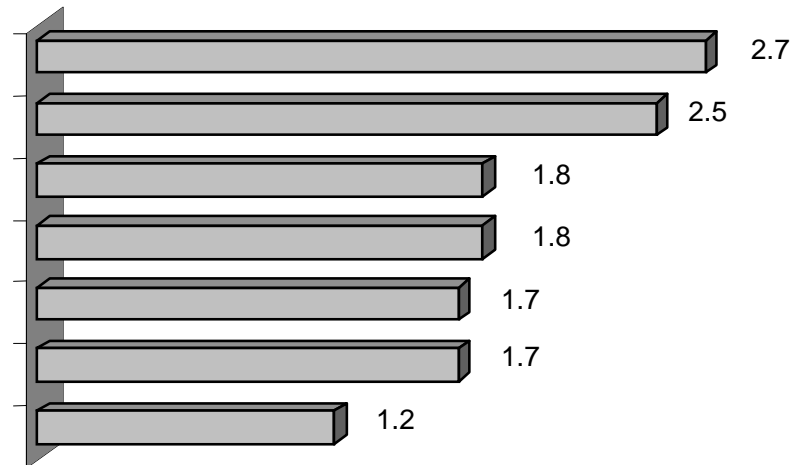

$0=$ no importance $; 3=$ high importance

Fig. 8. Importance of website functions.
Provide company information/ advertising
Improve customer relations
Improve customer service

Perform business transactions

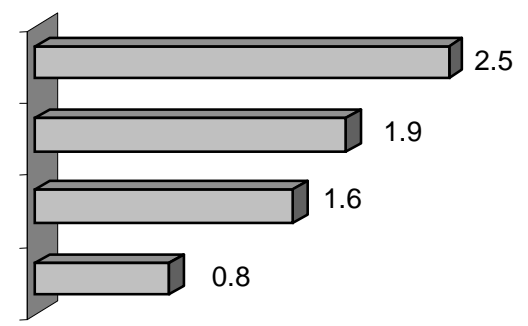

$0=$ no importance $; 3=$ high importance

Fig. 9. Factors stimulating current and future ICT adoption.

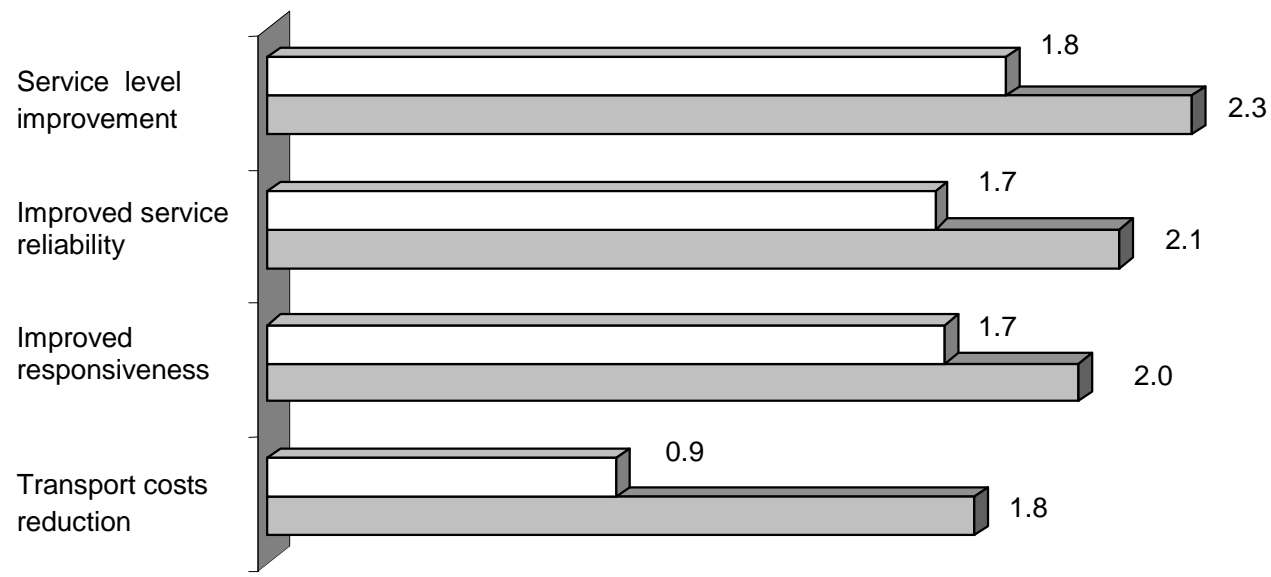

$\square$ Future $\square$ Current

$0=$ no importance $; 3=$ high importance 
Fig. 10. Factors inhibiting ICT adoption.
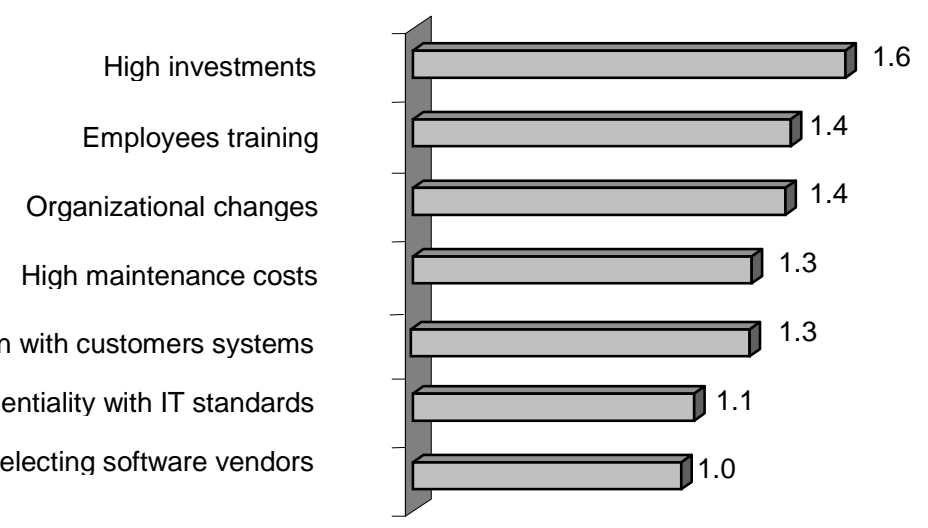

$0=$ no importance $; 3=$ high importance 